\title{
Analisis Pengaruh Kualitas Pelayanan Akademik terhadap Kepuasan Mahasiswa di Politeknik Negeri Balikpapan
}

\author{
Asri Setiarini $^{*}$, Saiful Ghozi ${ }^{2}$, Ida Suriana ${ }^{3}$ \\ ${ }^{1,2,3}$ Jurusan Akuntansi Politeknik Negeri Balikpapan \\ *asri.setiarini@poltekba.ac.id
}

\begin{abstract}
This study is expected to determine the influence of the dimensions of quality of service which include assurance, reliability, tangible, empathy, and responsiveness to Balikpapan Polytechnic student satisfaction. The method used in this research is quantitative approach with explanatory research. The test data which is used include vaalidity test, reliability test, classicassumption test (multicollinearity, normality, heteroscedasticity), multiple linear regression, goodness of fit ( $F$ test, $t$ test, the coeficient of determination). Population in this research is the students of Balikpapan Polytechnic. The sample used in this study was 90 respondents. The sampling technique is purposive sampling.The results of this study show that hypothesis 1 assurance variable, hypothesis 2 reliability variable, hypothesis 3 tangible variables, hypothesis 4 empathy variable, hypothesis 5 responsiveness variable, indicate signifant value which is smaller than $\alpha=0.05$ and is proven by $F$-calculate $>F$ - table. The results show that Ho is refuted and Ha is supported. It can be said that partial variable quality of service that include assurance, reliability, tangible, empathy, and responsiveness has a positive and significant impact on student satisfaction. Simultaneous test results that have been done show that empathy and tangible variables have a dominant influence on student satisfaction.
\end{abstract}

Keywords : Assurance, Reliability, Tangible, Empathy, Responsiveness, Student satisfaction

\begin{abstract}
Abstrak
Penelitian ini diharapkan dapat mengetahui pengaruh dimensi kualitas layanan yang meliputi assurance, reliability, tangible, empathy, dan responsiveness terhadap kepuasan mahasiswa politeknik Balikpapan. Metode yang digunakan dalam penelitian ini adalah pendekatan kuantitatif dengan penelitian explanatory. Data tes yang digunakan meliputi uji validitas, uji realibilitas, uji asumsi klasik (multikolinearitas, normalitas, heteroskedastisitas), regresi linear berganda, goodness of fit (uji F, uji t). Populasi dalam penelitian ini adalah mahasiswa Politeknik Negeri Balikpapan. Sampel yang digunakan dalam penelitian ini adalah 90 responden. Teknik pengambilan sampel adalah hasil sampling.Sampel purposive dari penelitian ini menunjukkan bahwa hipotesis 1 variabel assurance, hipotesis 2 variabel reliability, hipotesis 3 variabel tangibles, hipotesis 4 variabel empathy, hipotesis 5 variabel responsiveness, menunjukkan nilai significant yang lebih kecil dari $\alpha=0,05$ dan terbukti dengan F -calculate> F - tabel. Hasil penelitian menunjukkan bahwa Ho ditolak dan Ha didukung. Dapat dikatakan bahwa parsial variabel kualitas layanan yang meliputi jaminan, keandalan, nyata, empati, dan daya tanggap memiliki dampak positif dan signifikan terhadap kepuasan mahasiswa. Hasil tes simultan yang telah dilakukan menunjukkan bahwa empati dan variabel tangible memiliki pengaruh yang dominan terhadap kepuasan mahasiswa.
\end{abstract}

Kata kunci: Assurance, Keandalan, Tangible, Empathy, Responsiveness, kepuasan Mahasiswa

\section{Pendahuluan} Perguruan tinggi adalah lembaga profit sebagai tujuan utama, memberikan pemberi jasa dibidang pendidikan, walaupun pelayanan prima kepada mahasiswa dalam operasionalnya tidak mengedepankan 
merupakan keharusan seperti lembaga berorientasi profit. Perguruan tinggi didalam memberikan pelayanan memiliki ciri khusus yang tidak bisa disamakan dengan lembaga jasa lain diluar perguruan tinggi.

Pengelola perguruan tinggi sebagai salah satu bentuk perusahaan jasa tidak boleh berfikir bahwa semua produk atau jasa yang ditawarkannya pasti akan laku seluruhnya tanpa memperhatikan apa yang diinginkan oleh pelanggannya. Pihak pengelola perguruan tinggi harus melihat apa yang diinginkan oleh pelanggannya. Dengan kata lain, jika ingin meningkatkan nilai dan kepuasan di mata pelanggan yaitu mahasiswa dan masyarakat secara umum maka pengelola perguruan tinggi harus memperhatikan kualitas jasa (service quality) yang diberikan.

Jika pelanggan dalam hal ini mahasiswa dan masyarakat luas memiliki persepsi yang positif terhadap kualitas pelayanan lembaga tersebut, maka kepercayaan masyarakat terhadap perguruan tinggi juga akan mengalami peningkatan. Selanjutnya, hal ini akan berpengaruh pada kesetiaan mahasiswa dan masyarakat luas untuk terus menggunakan jasa perguruan tinggi tersebut dimasa yang akan datang.

Kepuasan pelanggan sangat banyak ditentukan oleh kualitas jasa yang dikehendaki konsumen, sehingga perguruan tinggi sebagai penyedia layanan pendidikan seharusnya menekankan pada pemberian layanan yang berkualitas guna memperoleh kepercayaan mahasiswa dan masyarakat luas. Kualitas pelayanan itu sendiri terdiri dari lima unsur, yaitu: bukti fisik (tangibles), keandalan (reliabilitas), daya tanggap (responsiveness), jaminan (assurance) dan empati (empathy).

\subsection{Perumusan Masalah}

Berdasarkan latar belakang diatas, maka peneliti dapat merumuskan masalah sebagai berikut:

1. Bagaimana pengaruh variabel Assurance (X1) terhadap kepuasan mahasiswa (Y) di Politeknik Negeri Balikpapan?

2. Bagaimana pengaruh variabel Reliability (X2) terhadap kepuasan mahasiswa (Y) di Politeknik Negeri Balikpapan?

3. Bagaimana pengaruh variabel Tangibles (X3) terhadap kepuasan mahasiswa (Y) di Politeknik Negeri Balikpapan?

4. Bagaimana pengaruh variabel Empathy (X4) terhadap kepuasan mahasiswa (Y) di Politeknik Negeri Balikpapan?

5. Bagaimana pengaruh variabel Responsives (X5) terhadap kepuasan mahasiswa (Y) di Politeknik Negeri Balikpapan?

\subsection{Tujuan Penelitian}

Tujuan dari penelitian ini adalah untu mengetahui pengaruh lima dimensi kualitas pelayanan di Politeknik Negeri Balikpapan terhadap tingkat kepuasan mahasiswa. 


\section{Metoda Penelitian}

Metode yang digunakan dalam penelitian ini adalah pendekatan kuantitatif dengan explanatory research. Populasi pada penelitian ini adalah para mahasiswa yang aktif di Politeknik Negeri Balikpapan. Teknik pengambilan sampel adalah purposive sampling dengan metode pengumpulan data yang digunakan yaitu kuesioner. Sampel dari populasi adalah 90 responden.
Teknik analisis data dalam penelitian ini adalah analisis regresi berganda. Analisis regresi berganda dilakukan untuk membuktikan hipotesis yang diajukan, menguji model atau kerangka penelitian yang diajukan. Untuk lebih jelasnya dibawah ini adalah kerangka penelitian dalam penelitian ini:

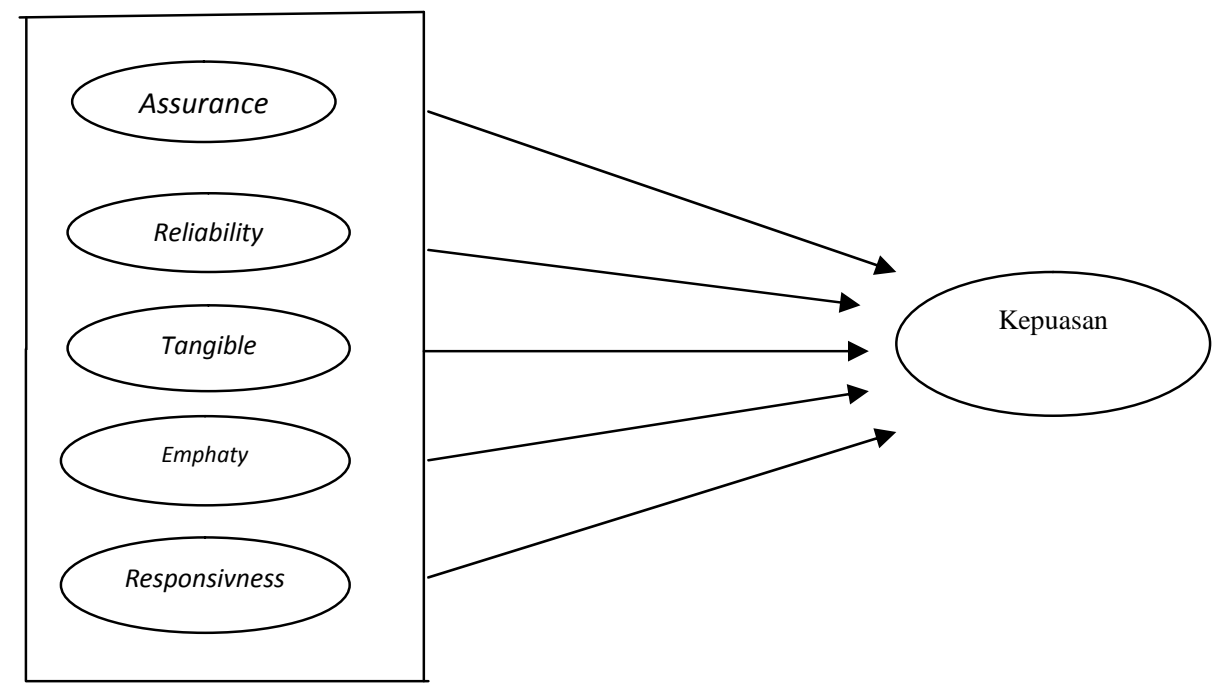

Kualitas Pelayanan

Gambar 1. Kerangka Penelitian

\subsection{Uji Signifikan Simultan (uji F)}

Uji F pada dasarnya untuk menunjukkan apakah semua variabel independen atau bebas yang dimasukan dalam model mempunyai pengaruh secara bersama-sama terhadap variabel dependen/ terkait (Ghozali, 2012).

\subsection{Uji Signifikan Pengaruh Parsial (uji t)}

Uji $t$ digunakan untuk menguji perbedaan dua rata-rata populasi yang datanya berbentuk interval. Uji t digunakan untuk menguji perbedaan dua buah rata-rata yang dapat berasal dari distribusi sampel yang berbeda dan juga sampel yang berhubungan (Ghozali, 2012).

\section{HASIL PENELITIAN}

\subsection{Hasil Uji Normlitas}

Uji normalitas bertujuan untuk menguji apakah dalam sebuah model regresi, variabel 
terikat, variabel bebas atau keduanya mempunyai distribusi normal atau tidak. Suatu data berdistribusi normal dilihat dari penyebarannya pada sumbu diagonal dari grafik dengan dasar keputusan sebagai berikut (Ghozali, 2012):

a. Jika data menyebar disekitar garis diagonal dan mengikuti arah garis diagonal, maka model regresi memenuhi normalitas.

b. Jika data menyebar jauh dari garis diagonal dan tidak mengikuti arah garis diagonal, maka model regresi tidak memenuhi normalitas.

Hasil analisis SPSS dapat dilihat pada gambar 2 dibawah ini:

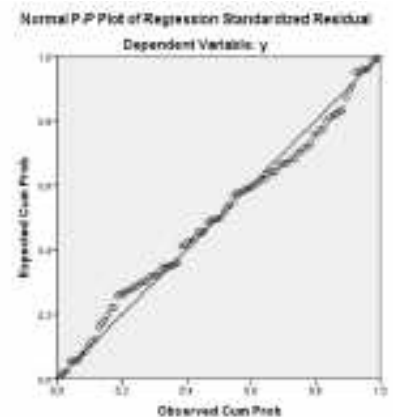

Gambar 2. Hasil Uji Normalitas

\subsection{Hasil Uji Multikolinearitas}

Uji multikolonieritas bertujuan untuk menguji apakah model regresi ditemukan adanya korelasi antar variabel bebas (independen). Multikolonieritas dapat pula dilihat dari nilai tolerance dan variance inflation factor (VIF). Tolerance mengukur variabel independen yang terpilih yang tidak dijelaskan oleh variabel independen lainnya. Jadi nilai tolerance yang rendah sama dengan nilai VIF tinggi (karena $\mathrm{VIF}=1 /$ tolerance) nilai cut off yang umum di pakai untuk menunjukkan adanya multikolonieritas adalah nilai tolerance $>0,10$ atau sama dengan nilai VIF < 10 (Ghozali, 2012). Untuk lebih jelasnya dapat dilihat pada tabel dibawah ini:

Tabel 1. Collinearity Statistics

\begin{tabular}{clcc}
\hline \multirow{2}{*}{ No } & \multirow{2}{*}{ Variabel } & \multicolumn{2}{c}{ Collinearity Statistics } \\
\cline { 3 - 4 } & & Tolerance & VIF \\
\hline 1 & Assurance (X1) & .414 & 1.079 \\
\hline 2 & Reliability (X2) & .489 & 2.044 \\
\hline 3 & Tangible (X3) & .686 & 1.458 \\
\hline 4 & Emphaty (X4) & .927 & 1.079 \\
\hline 5 & Responsive (X5) & .624 & 1.601 \\
\hline
\end{tabular}

\subsection{Hasil Uji Heteroskedastisitas}

Uji heteroskedastisitas bertujuan untuk menguji apakah dalam model regresi terjadi ketidaksamaan varian dari residual suatu pengamatan ke pengamatan yang lain, maka disebut homoskedastisitas dan jika varian berbeda disebut heteroskedastisitas. Model regresi yang baik adalah yang homokedastisitas atau tidak terjadi heteroskedastisitas (Ghozali, 2009). Cara untuk mendeteksi ada atau tidaknya heterokedastisitas yaitu dengan melihat grafik plot (scatterplot) antara nilai prediksi variabel terikat (dependen/ZPRED) dengan residualnya SRESID.

Dasar analisis untuk scatterplot yaitu jika ada pola tertentu seperti titik yang ada membentuk pola tertentu yang teratur (bergelombang, melebar kemudian menyempit), maka kemudian mengindikasikan 
terjadinya heteroskedastisitas. Sebaliknya jika tidak ada pola yang jelas, serta titik menyebar di atas dan di bawah angka 0 (nol) pada sumbu Y, maka tidak terjadi heteroskedastisitas (Ghozali, 2009). Grafik plot (scatterplot) dapat dilihat pada Gambar 3 dibawah ini:

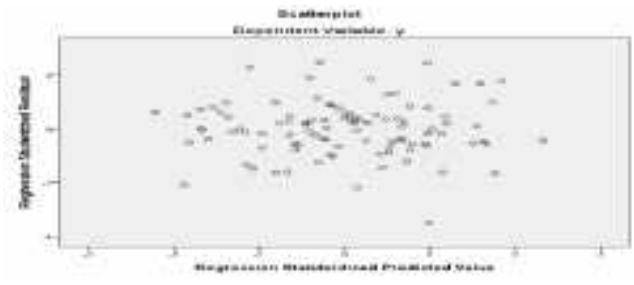

Tabel 2. Hasil Analisis Regresi Linear Berganda

\begin{tabular}{cllccl}
\hline $\begin{array}{c}\text { Dependen } \\
\mathbf{Y}\end{array}$ & Independen $\mathbf{X}$ & $\mathbf{B}$ & $\mathbf{t}$ & Sig & \multicolumn{1}{c}{ Pengaruh } \\
\hline \multirow{4}{*}{$\begin{array}{c}\text { Kepuasan } \\
\text { Mahasiswa }\end{array}$} & Assurance & .401 & 4.759 & .000 & Positif dan Signifikan \\
\cline { 2 - 7 } & Reliability & .404 & 2.549 & .012 & Positif dan Signifikan \\
\cline { 2 - 7 } & Tangible & .412 & 3.686 & .000 & Positif dan Signifikan \\
\cline { 2 - 7 } & Empaty & -4.71 & -2.118 & .037 & Negatif dan Signifikan \\
\cline { 2 - 6 } & Responsive & .374 & 2.621 & .010 & Positif dan Signifikan \\
\cline { 2 - 6 } & (constant) & 1.885 & & & \\
\hline
\end{tabular}

F hitung $=46.217$

$\mathrm{R}=0.843$

$\mathrm{t}$ table $=1.984$

$\mathrm{F}$ table $=1.77$

Adjusted R Square $=0.695$

Berdasarkan hasil uji statistik regresi linear berganda dengan program SPSS 22, maka model persamaan regresi yang dapat dituliskan dari hasil statistik tersebut adalah persamaan regresi sebagai berikut:

Hasil yang diperoleh bahwa Variabel kualitas pelayanan memiliki koefisien regresi dengan arah positif. Hasil uji t menunjukkan bahwa seberapa jauh satu Variabel independen secara individual dalam menerapkan variasi Variabel dependen. Nilai adjusted R Square 0.695 atau $69.5 \%$ yang
Gambar 3. Hasil Uji Heteroskedastisitas

\subsection{Hasil Uji Regresi Linear Berganda}

Hasil analisis tentang pengaruh variabelvariabel bebas yaitu faktor-faktor kualitas layanan akademik terhadap kepuasan mahasiswa Politeknik Negeri Balikpapan dapat dilihat pada tabel 2 dibawah ini. 
2. Variabel Relibility (X2) berdasarkan tabel $4.16 \mathrm{di}$ atas 0.404 atau $40.4 \%$, t-hitung 2.549, dengan p-value tingkat Sig. 0.012.

3. Variabel Tangible (X3) berdasarkan tabel 4.16 di atas 0.412 atau $41.2 \%$, t-hitung 3.686, dengan p-value tingkat Sig. 0.000.

4. Variabel Emphaty (X4) berdasarkan tabel 4.16 di atas -0.471 atau $-47.1 \%$, t-hitung 2.118, dengan p-value tingkat Sig. 0.037.

5. Variabel Responsiveness (X5) berdasarkan tabel 4.16 di atas 0.374 atau $37.4 \%$, thitung 2.621, dengan p-value tingkat Sig. 0.010 .

\section{$Y=0.401 X 1+0.404 X 2+0.412 X 3+-$}

\section{$0.471 \times 4+0.374 \times 5$}

Hasil perhitungan yang diperoleh dari nilai f-hitung 46.217. Artinya bahwa secara bersama-sama Variabel bebas yang terdiri assurance (X1), reliability (X2), tangible (X3), empathy (X4), responsiveness (X5) berpengaruh secara signifikan terhadap Variabel kepuasan mahasiswa (Y). hasil variabel yang diuji secara bersama-sama bisa dibuktikan dengan f-tabel sebesar 1.77.

\subsection{Hasil Pengujian Hipotesis}

\section{a. Pengujian Hipotesis Variabel Assurance}

Hipotesis H1, berdasarkan hasil uji statistik variabel assurance (X1) terhadap kepuasan mahasiswa menunjukkan t-hitung sebesar 4.759 dan t-tabel 1.984 dengan probabilitas atau tingkat Sig. sebesar 0.000. Nilai signifikansi menunjukkan lebih kecil dari $\alpha=0.05$ dan dibuktikan t-hitung $>\mathrm{t}$ tabel. Hasil tersebut menunjukkan Ho ditolak dan Ha diterima, bisa dikatakan secara parsial variabel assurance memiliki pengaruh yang positif dan signifikan terhadap kepuasan mahasiswa. Maka kesimpulannya Ho ditolak dan Ha diterima berarti hipotesis 1 diterima.

\section{b. Pengujian Hipotesis Variabel Reliability}

Hipotesis H2, berdasarkan hasil uji statistik variabel reliability (X2) terhadap kepuasan mahasiswa menunjukkan t-hitung sebesar 2.549 dan t-tabel 1.984 dengan probabilitas atau tingkat Sig. sebesar 0.012. Nilai signifikansi menunjukkan lebih kecil dari $\alpha=0.05$ dan dibuktikan t-hitung $>\mathrm{t}$ tabel. Hasil tersebut menunjukkan Ho ditolak dan Ha diterima, bisa dikatakan secara parsial variabel reliability memiliki pengaruh yang positif dan signifikan terhadap kepuasan mahasiswa. Maka kesimpulannya Ho ditolak dan Ha diterima berarti hipotesis 2 diterima.

\section{c. Pengujian Hipotesis Variabel Tangible}

Hipotesis H3, berdasarkan hasil uji statistik variabel tangible (X3) terhadap kepuasan mahasiswa menunjukkan t-hitung sebesar 3.686 dan t-tabel 1.984 dengan probabilitas atau tingkat Sig. sebesar 0.000. Nilai signifikansi menunjukkan lebih kecil dari $\alpha=0.05$ dan dibuktikan t-hitung $>\mathrm{t}-$ tabel. Hasil tersebut menunjukkan Ho ditolak dan Ha diterima, bisa dikatakan secara parsial variabel tangible memiliki pengaruh yang 
positif dan signifikan terhadap kepuasan mahasiswa. Maka kesimpulannya Ho ditolak dan Ha diterima berarti hipotesis 3 diterima.

\section{d. Pengujian Hipotesis Variabel Emphaty}

Hipotesis H4, berdasarkan hasil uji statistik variabel emphaty (X4) terhadap kepuasan mahasiswa menunjukkan t-hitung sebesar -2.118 dan t-tabel 1.984 dengan probabilitas atau tingkat Sig. sebesar -0.037 . Nilai signifikansi menunjukkan lebih kecil dari $\alpha=0.05$ dan dibuktikan t-hitung > ttabel. Hasil tersebut menunjukkan Ho ditolak dan Ha diterima, bisa dikatakan secara parsial variabel emphaty memiliki pengaruh yang positif dan signifikan terhadap kepuasan mahasiswa. Maka kesimpulannya Ho ditolak dan Ha diterima berarti hipotesis 4 diterima.

\section{e. Pengujian Hipotesis Variabel \\ Responsiveness}

Hipotesis H5, berdasarkan hasil uji statistik variabel responsiveness terhadap kepuasan mahasiswa menunjukkan t-hitung sebesar 2.621 dan t-tabel 1.984 dengan probabilitas atau tingkat Sig. sebesar 0.010. Nilai signifikansi menunjukkan lebih kecil dari $\alpha=0.05$ dan dibuktikan t-hitung > t-tabel. Hasil tersebut menunjukkan Ho ditolak dan Ha diterima, bisa dikatakan secara parsial variabel responsiveness memiliki pengaruh yang positif dan signifikan terhadap kepuasan mahasiswa. Maka kesimpulannya
Ho ditolak dan Ha diterima berarti hipotesis 5 diterima.

\section{Kesimpulan}

Hasil penelitian menunjukkan bahwa kelima dimensi kualitas pelayanan terbukti berpengaruh secara signifikan terhadap kepuasan pelanggan. Dilihat dari koefisien variabel kualitas pelayanan yang meliputi assurance, reliability, tangible, emphaty, danresponsivenessmendapat 46.214, dimana hasil uji statistic variabel kualitas pelayanan berpengaruh positif dan signifikan terhadap kepuasan mahasiswa.. Variabel kualitas pelayanan berdasarkan emphaty dan tangible adalah faktor yang dominan berpengaruh terhadap kepuasan mahasiswa Politeknik Negeri Balikpapan. Hal ini berarti bahwa kepuasan yang dirasakan lebih banyak ditentukan oleh pemberian layanan berupa perhatian yang lebih bersifat pribadi kepada mahasiswa serta bukti fisik seperti kelengkapan fasilitas dan peralatan dalam proses belajar, serta kebersihan dan kenyamanan lingkungan belajar.

\section{Saran}

Untuk variabel kualias pelayanan yang mendapatkan tanggapan tidak baik dan sangat tidak baik perlu diperhatikan lagi. Untuk aspek variabel emphaty sebaiknya dosen dan laboran/instruktur diberikan pelatihan tentang 
cara mengajar yang menyenangkan sehingga

mahasiswa marasa puas dan dapat menerima

materi yang diajarkan dengan baik.

\section{Daftar Pustaka}

Changsu Kim, Yeongnam University, Korea.,Weihong Zhao, Jiangxi Normal University, China., Kyung Hoon Yang, University of Wisconsin-La Cross, USA, 2008, An Empirical Study on Integrated Framework of e-CRM in Online Shopping: Evaluating The Relationships Among Perceived Value, Satisfaction and Trust Based on Customer's Perspectives.

Ferdinand, Augusty. 2006. Metode Penelitian Manajemen. Edisi 2, Badan Penerbit Universitas Diponegoro, Semarang.

Ghozali, Imam. 2008. Konsep \& Aplikasi Program AMOS 16. Badan Penerbit Universitas Diponegoro, Semarang.

Harahap,S Sofyan dkk, 2006," Kepuasan pelanggan Pada Bank Islam Studisuatu Bank Islam di Indonesia", Media Riset Bisnis dan manajemen, vol. 6, No. 2, Agustus

Juan Meng, Kevin M Elliot. 2009. Investigating Structural Relationships Between Service Quality, Switching Costs, and Customer Satisfaction. The Journal of Applied Business and Economics, Thunder Bay: May, Volume 9 edisi 2.

Kotler, Philip. 1997. Manajemen Pemasaran. Salemba Empat, Jakarta.

Kotler, Philip. 2000. Marketing Management. Millennium Edition, Prentice Hall International, Inc. New Jersey.

Kotler, Philip, et al. 2004. Manajemen Pemasaran Perspektif Asia. Edisi 3, PT. Indeks, Jakarta.

Kotler, Philip. 2008. Manajemen Pemasaran. Jilid I, Edisi 12, PT Macanan Jaya Cemerlang, Jakarta.

Kriyantono, Rachmat. (2006). Teknik Praktis Riset Komunikasi. Jakarta : Kencana Prenada Media Group.
Lupiyoadi, Rambat. 2001. Manajemen Pemasaran Jasa: Teori dan Praktik. Edisi Pertama. Salemba Empat, Jakarta.

Othman, Abdul, Qawi \& Owen, Lynn. 2001. "Adopting and Measuring Customer Service Quality (SQ) in Islamic Banks: A Case Study in Kuwait Finance House". International Journal of Islamic Financial Services, Vol. 3, No. 1, April - June.

Othman, Abdul, Qawi \& Owen, Lynn. 2002. "The Multi Dimensionality of CARTER Model to Measure Customer Service Quality (SQ) in Islamic Banking Industry: A Study in Kuwait Finance House". International Journal of Islamic Financial services, Vol. 3, No. 4, Januari - March. 